УДК 616.36-002-022.7:[ 578.83HВV+578.83HCV ]-078:615.38

\title{
Динаміка виявлення маркерів гепатів В та С у донорів крові та пацієнтів як показник якості відбору донорських кадрів
}

\author{
Саламаніна А. О., Юнацька О. В., Третьякова І. О.
}

ДУ «Науково-практичний медичний центр дитячої кардіології та кардіохірургії МОЗ України» (Київ)

\begin{abstract}
Важливим питанням безпеки донорської крові є поширеність інфекцій, які передаються гемотрансмісивним шляхом, зокрема вірусних гепатитів В та С. Представлено результати обстеження донорів і пацієнтів у відділі трансфузіології на маркери вірусних гепатитів В та С за період 2013-2015 рр. Дослідження проводилися методами імунохемілюмінісцентного (IXЛА) та імуноферментного аналізу (IФА). Матеріалом для ретроспективного дослідження слугувала сироватка крові 22144 донорів і пацієнтів, у тому числі 9090 зразків від штатних донорів, 1450 зразків від осіб, шо виявили бажання стати донорами, та 11604 зразки крові пацієнтів за дослідний період. Серед донорів було виявлено 23 зразки, позитивні на наявність антитіл до гепатиту C, що становить $0,22 \%$, та 6 зразків, позитивних на наявність поверхневого антигену гепатиту $\mathrm{B}$, що становить $0,057 \%$. Виявлення маркерів гепатиту С у донорів має стабільну тенденцію до зниження. Залишається стабільно низьким виявлення HBsAg у штатних донорів крові, та спостерігається зниження виявлення HBsAg в осіб, які виявили бажання стати донорами.
\end{abstract}

Ключові слова: гемотрансмісивні інфекції, гепатит $B$, гепатит $C$, гемотрансфузія, імунохемілюмінісцентний аналіз (ІХЛА), імуноферментний аналіз (IФА).

Переливання компонентів крові щорічно сприяє порятунку мільйонів життів, збільшує очікувану тривалість і якість життя пацієнтів і є додатковим засобом для проведення складних медичних процедур. Згідно з цілями ВОО3, зниження дитячої смертності, зміцнення здоров'я матерів і посилення боротьби проти ВІЛ/ СНІДу, гепатитів та інших хвороб можливе лише у випадку, коли належна увага буде приділена наявності, безпеці та якості компонентів і препаратів крові. Запобігання передаггю гемотрансмісивних інфекцій має вирішальне значення для планування ефективної політики, стратегії, системи забезпечення якості, а також регламентуючих документів, що стосуються забору, тестування, переробки та поставки компонентів крові.

Вірусні гепатити В та С належать до антропонозних вірусних інфекцій із групи гепатитів із парентеральним механізмом передачі. В усьому світі гепатитами В і C інфіковано близько 400 млн. осіб, що більш ніж у 10 разів перевищує кількість людей з ВІЛ.

Гепатит В - захворювання печінки, викликане ДНК-вмісним вірусом гепатиту В (HBV). Хронічна інфекція, спричинена цим вірусом, призводить до прогресивного запалення печінки і розвитку фіброзу. Вірус гепатиту В - онкогенний вірус із найбільш високим ризиком розвитку гепатоцелюлярної карциноми $[10,12]$. Згідно з різними оцінками, у світі на- 
раховується 240 млн. тільки носіїв вірусного гепатиту В, близько 780 тис. осіб щорічно помирають від захворювань, спричинених гепатитом В, у результаті хронічної інфекції, від цирозу та раку печінки помирає 650 тис. людей, ще 130 тис. людей - від гострого гепатиту В $[1,11]$.

Незважаючи на достатньо сприятливий перебіг хронічного гепатиту В у ранньому дитинстві та підлітковому віці, у 3-5\% хронічних носіїв розвивається цироз печінки, а у $0,001-0,03 \%$ - гепатоцелюлярна карцинома до настання повноліття [5, 6].

Вважається, що хронічний перебіг вірусного гепатиту В розвивається у $2-10 \%$ дорослих, що перенесли гостру форму захворювання. Вірогідність розвитку хронічного ураження печінки зростає при інфікуванні внутрішньоутробно, а також у грудному і ранньому дитячому віці. При інфікуванні на 1-му році життя частота хронізації досягає 70-90\%, в 2-3 роки $-40-70 \%$, у 4-6 років $-10-40 \%$, а у дітей старших 8 років $-6-10 \%$ $[3,9,10]$.

Єдиним методом профілактики вірусного гепатиту В та, шо особливо важливо в дитячому віці, його хронізації та фульмінантного перебігу, є вакцинація. У Державній установі «Науково-практичний медичний центр дитячої кардіології та кардіохірургії МОЗ України» оперуються діти з перших годин життя і діти, які мають тимчасові протипоказання до щеплення та за віком не встигли отримати весь курс вакцинації, відтак питання інфекційної безпеки гемотрансфузії для них стоїть дуже гостро. Це зумовлює актуальність вивчення частки донорів, які мають позитивні маркери гепатиту В [8].

Вірусний гепатит $\mathrm{C} \epsilon$ однією з важливих проблем сучасної медицини. За оцінкою експертів Всесвітньої організації охорони здоров'я (ВОО3), у світі на хронічну форму вірусного гепатиту С страждає 130-150 млн. осіб, 700 тис. осіб щороку помирають від ускладнень цього захворювання [2]. У $30 \%$ осіб із хронічною формою гепатиту С прогнозується розвиток цирозу печінки та гепатоцелюлярної карциноми. Розвиток цирозу печінки, як кінцевої стадії хронічного гепатиту С, у дитячому віці, за даними різних авторів, становить від $0-4 \%$ [14-17] до 8-10\% [18, 19].

За даними ВОО3, носійство збудника гепатиту С становить 83,3-95,9 осіб на 100 тис. населення. Найвищий рівень інфікованості реєструється в містах. Більше половини інфікованих у всьому світі - особи молодого віку (від 18 до 39 років). Таким чином, вірусний гепатит С належить до соціально значущих захворювань. За даними Центру медичної статистики МО3 України за 2015 р., в Україні поширеність хронічного вірусного гепатиту С серед населення складає 356907 осіб (782,7 на 100 тис. населення), захворюваність 28949 осіб (63,5 на 100 тис. населення), у тому числі у дітей поширеність на вірусний гепатит складає 1999 осіб (0,25\% на 1000$)$, захворюваність - 299 осіб $(0,04 \%$ на 1000) [20].

Згідно з даними МО3, Україну відносять до країн із середньою поишреністю вірусного гепатиту C: близько $3 \%$ населення вважається інфікованим. Але, за прогнозами фахівців, насправді ця цифра може сягати 5-8\%, а в деяких регіонах локальні дослідження Державної санітарно-епідеміологічної служби України виявили інфікованість до 10-12\%. За даними ВООЗ, поширеність гепатиту С серед населення України перевищує 5\% [16].

Достовірної статистики щодо поширеності вірусних гепатитів не має жодна країна, оскільки для іiі отримання необхідний тотальний скринінг населення, що фактично неможливо. У випадку латентних інфекційних процесів, таких як гепатит С, статистика має доволі орієнтовний характер [6].

Значним заходом для зменшення поширеності вірусних гепатитів В та С у донорів крові $є$ забезпечення ретельним медичним відбором донорів з обов'язковим передтестовим консультуванням. Також слід зазначити, що у відстороненні від донорства значно допомагає своєчасне отримання 3 лікувально-профілактичних закладів даних про захворювання осіб або наявність у них носійства збудників інфекцій, згідно з єдиним реєстром з Київського міського центру крові.

Також важливим аспектом і метою попередження поширення гемотрансмісивних інфекцій є карантинізація донорської плазми на 180 діб з моменту заготівлі згідно з наказу МОЗ № 385 від 01.08.2005 р. «Про інфекційну безпеку донорської крові та її компонентів». Дієвими засобами для зменшення поширеності гепатиту С та В гемотрансфузійним шляхом є ретельний відбір донорських кадрів, якісний скринінг крові на наявність антитіл до вірусу гепатиту C та поверхневого антигену гепатиту В, опромінення компонентів крові на пристрої для інактивації вірусів у плазмі Maco Pharma Macotronic B2, лейкофільтрація та раціональне клінічне застосування гемотрансфузійних середовищ. Усі ці методи активно використовуються в ДУ «Науково-практичний медичний центр дитячої кардіології та кардіохірургії МОЗ України». Для новонароджених із пренатально встановленими критичними вродженими вадами серця, які потребують проведення кардіохірургічного втручання в ранньому неонатальному періоді, запроваджено програму заготівлі аутологічної крові.

Сучасний стан проблеми зумовлює актуальність вивчення поширеності гепатитів В та С у донорів крові для оцінки якості відбору донорських кадрів, оскільки організація та контроль інфекційної безпеки гемотрансфузійної терапії є пріоритетним завданням відділу трансфузіології.

Мета роботи - виявлення позитивних результатів обстежень на маркери гепатитів В та С серед штатних 
донорів та осіб, що виявили бажання стати донорами. Для реалізації мети були поставлені такі завдання: провести обстеження зразків донорської крові на наявність антитіл до вірусного гепатиту C та HBsAg як маркера гепатиту B; провести ретроспективний аналіз даних про поширення гепатитів В і C серед штатних донорів та осіб, що виявили бажання стати донорами; проаналізувати динаміку інфікованості донорів.

Матеріали та методи. Матеріал для ретроспективного дослідження становила сироватка крові 22144 донорів і пацієнтів, у тому числі 9090 зразків від штатних донорів, 1450 зразків від осіб, що виявили бажання стати донорами, та 11604 зразки крові пацієнтів, які знаходились на лікуванні та з приводу кардіохірургічного втручання за період 2013-2015 рр. Обстеження проводили на базі лабораторії діагностики та профілактики СНІД та інших інфекцій (гепатитів В, С, сифілісу) відділу трансфузіології. Обробка даних здійснювалася за допомогою програми Excel 2010.

Скринінг на маркери гепатитів В і C проводився методом імунохемілюмінесцентного аналізу (IXЛА) на аналізаторі закритого типу Abbott Arhitec i 1000sr та методом імуноферментного аналізу (ІФА) на аналізаторі Thermo Electron Corporation Multiskan Ascent. Для діагностики методом IXЛА для виявлення наявності поверхневого антигену вірусу гепатиту В застосовувалися тест-системи HBsAg QII Abbott Diagnostic (США), для виявлення сумарних антитіл до вірусу гепатиту C - тест-система anti-HCV Abbott Diagnostic (США). Для проведення дослідження ІФА використовували такні тест-системи: для виявлення поверхневого антигену гепатиту B (HBsAg) - «DIA-HBV» Dia-Prof Med Україна, для виявлення антитіл до вірусу гепатиту C «Vitrotest- anti-HCV» RAMINTEK Україна.

Порівняно з імуноферментним аналізом хемілюмінесцентний аналіз має низку суттєвих переваг:

- високочутливий і специфічний;

- має більшу швидкість отримання результату (3040 хв.), що важливо для екстрених обстежень;

- повністю автоматизований;

- продуктивний (100 досліджень за годину).

Перевагою ІФА як методу є використання мінімальних об'ємів досліджуваного зразка, що актуально в педіатричній практиці.

Основним методом скринінгової діагностики гепатиту В $є$ визначення поверхневого антигену вірусу гепатиту B (HBsAg). HBsAg - основний і перший маркер інфікування вірусом гепатиту В. Білок зовнішньої HBV оболонки є його поверхневим антигеном - HBsAg. HBsAg може бути виявлений у крові обстежуваних в інкубаційний період зазвичай через 3-5 тижнів після інфікування за відсутності клінічної картини гепатиту $[4,7]$. Концентрація HBsAg у крові інфікованих вірусом варіює в широкому діапазоні - від 0,01 нг/мл до 500 мкг/мл. Слід зазначити, що тільки частина HBsAg, що утворюється при реплікації $\mathrm{HBV}$, використовується для побудови нових вірусних частинок, основна ж його кількість надходить у кров інфікованих осіб у формі сферичних частинок діаметром 22 нм. При хронічному вірусному гепатиті B HBsAg постійно виявляється у крові хворих [10, 11].

Специфічними маркерами діагностики вірусного гепатиту C слугують антитіла до вірусу гепатиту C анти-HCV IgM та IgG. Інкубаційний період вірусного гепатиту С достатньо тривалий і становить від 20 до 150 діб (у середньому 40-50 діб). Гостра фаза інфекції майже у $80 \%$ дорослих людей протікає у вигляді субклінічної безжовтушної форми.

Гуморальна імунна відповідь у гострій фазі HCVінфекції не йде очікуваним класичним шляхом антитілоутворення, оскільки антитіла класу IgM (гепатит C) HCV можуть виявлятися одночасно або навіть пізніше за анти-HCV (гепатит C) IgG. Тому виявлення анти-HCV IgM не може бути використано як маркер гострої інфекції. Подовжена циркуляція анти-core IgM (понад 3-5т) є прогностичним фактором розвитку персистуючої інфекції, а поява таких антитіл при ХГС свідчить про реактивацію збудника та загострення процесу $[3,11]$.

Сучасні імуноферментні тест-системи для діагностики гепатиту С основані на визначенні антитіл до окремих вірусних антигенів (core, NS3, NS4, NS5) і забезпечують отримання достовірних результатів. Також для лабораторної діагностики гепатиту С застосовують підтверджуючі тести -рекомбінантний імуноблотинг або вестерн-блот, що дозволяють виявити антитіла до різних структурних і неструктурних білків $\mathrm{HCV}[3,11]$.

Результати та обговорення. На наявність маркерів гепатитів В та С за період 2013-2015 років було обстежено зразки сироватки крові 22144 донорів і пацієнтів, у тому числі 9090 зразків від штатних донорів, 1450 зразків від осіб, що виявили бажання стати донорами, та 11604 зразки сироватки крові пацієнтів.

При обстеженні крові донорів за період з 2013 по 2015 р. було виявлено 23 зразки, позитивні на наявність антитіл до гепатиту С, що становить $0,22 \%$, при цьому частота виявлення позитивних зразків серед штатних донорів становить 10 осіб, що відповідає $0,11 \%$, а серед осіб, що виявили бажання стати донорами, -13 осіб (0,90\%). У пацієнтів виявлено 257 позитивних зразків, що відповідає частоті 2,2\% (табл. 1).

При обстеженні зразків сироватки крові донорів за період з 2013-2015 рр. на наявність поверхневого антигену гепатиту В було виявлено 6 позитивних зразків, що становить $0,057 \%$, при цьому частота позитивних зразків серед штатних донорів становить 4 особи $(0,044 \%)$, а серед осіб, що виявили бажання стати донорами, -2 особи $(0,14 \%)$. У пацієнтів виявлено 65 позитивних зразків, що відповідає $0,56 \%$ (табл. 2). 


\section{Таблиця 1}

Розподіл маркерів гепатиту C серед донорів та пацієнтів

\begin{tabular}{|c|c|c|c|c|}
\hline $\begin{array}{l}\text { Роки } \\
\text { обсте- } \\
\text { ження }\end{array}$ & Результати & $\begin{array}{c}\text { Донори } \\
\text { штатні }\end{array}$ & $\begin{array}{c}\text { Особи, які } \\
\text { виявили ба- } \\
\text { жання бути } \\
\text { донорами }\end{array}$ & Пацієнти \\
\hline \multirow{3}{*}{2013} & $\begin{array}{l}\text { кількість обсте- } \\
\text { жень }\end{array}$ & 3326 & 336 & 3804 \\
\hline & $\begin{array}{l}\text { кількість позитив- } \\
\text { них результатів }\end{array}$ & 7 & 6 & 81 \\
\hline & $\%$ & 0,21 & 1,79 & 2,13 \\
\hline \multirow{3}{*}{2014} & $\begin{array}{l}\text { кількість обсте- } \\
\text { жень }\end{array}$ & 2919 & 480 & 3882 \\
\hline & $\begin{array}{l}\text { кількість позитив- } \\
\text { них результатів }\end{array}$ & 3 & 4 & 86 \\
\hline & $\%$ & 0,10 & 0,83 & 2,22 \\
\hline \multirow{3}{*}{2015} & $\begin{array}{l}\text { кількість обсте- } \\
\text { жень }\end{array}$ & 2845 & 634 & 3918 \\
\hline & $\begin{array}{l}\text { кількість позитив- } \\
\text { них результатів }\end{array}$ & - & 3 & 90 \\
\hline & $\%$ & 0,00 & 0,47 & 2,30 \\
\hline
\end{tabular}

Аналіз результатів досліджень, проведених упродовж 2013-2015 років, показав, що виявлення маркерів гепатиту С у пацієнтів має тенденцію до незначного зростання. При цьому частота виявлення позитивних результатів 2,3\%, яка мала місце у 2015 році, відповідає оцінкам експертів ВООЗ по Європейському регіону та даним прес-служби МОЗ України щодо поширеності хронічних вірусних гепатитів серед населення України [20].

Виявлення маркерів гепатиту С серед донорів має стабільну тенденцію до зниження. Серед штатних донорів у 2015 році не виявлено жодного випадку позивного дослідження на маркери гепатиту C, що зумовлено якісним відбором донорських кадрів на переддонаційному етапі. Серед осіб, які виявили бажання стати донорами, показник виявлення анти-HCV антитіл знизився у 3,8 рази за період дослідження і становить $0,47 \%$ у 2015 році.

Згідно 3 результатами дослідження, частота виявлення HBsAg у пацієнтів становить у середньому 0,56\% за три роки дослідження. Це вдвічі нижче за дані статистики Центральної санітарно-епідеміологічної станції МО3 України (1,5-2\%), що зумовлено переважанням серед пацієнтів дітей різного віку, які мають менше факторів ризику виникнення захворювань та частина з яких отримали вакцинацію.

Залишається стабільно низьким виявлення $\mathrm{HBsAg}$ у штатних донорів крові, та спостерігається зниження виявлення HBsAg в осіб, які виявили бажання стати донорами.

\section{Таблиця 2}

Розподіл виявлення маркеру (HBsAg) гепатиту B серед донорів та пацієнтів

\begin{tabular}{|c|c|c|c|c|}
\hline $\begin{array}{l}\text { Роки } \\
\text { обсте- } \\
\text { ження }\end{array}$ & Результати & $\begin{array}{r}\text { Донори } \\
\text { штатні }\end{array}$ & $\begin{array}{l}\text { Особи, які вия- } \\
\text { вили бажання } \\
\text { бути донорами }\end{array}$ & Пацієнти \\
\hline \multirow{3}{*}{2013} & $\begin{array}{l}\text { кількість обсте- } \\
\text { жень }\end{array}$ & 3326 & 336 & 3804 \\
\hline & $\begin{array}{l}\text { кількість } \\
\text { позитивних } \\
\text { результатів } \\
\end{array}$ & - & 1 & 26 \\
\hline & $\%$ & 0,00 & 0,30 & 0,68 \\
\hline \multirow{3}{*}{2014} & $\begin{array}{l}\text { кількість обсте- } \\
\text { жень }\end{array}$ & 2919 & 480 & 3882 \\
\hline & $\begin{array}{l}\text { кількість } \\
\text { позитивних } \\
\text { результатів }\end{array}$ & 2 & 1 & 15 \\
\hline & $\%$ & 0,07 & 0,21 & 0,39 \\
\hline \multirow{3}{*}{2015} & $\begin{array}{l}\text { кількість обсте- } \\
\text { жень }\end{array}$ & 2845 & 634 & 3918 \\
\hline & $\begin{array}{l}\text { кількість } \\
\text { позитивних } \\
\text { результатів }\end{array}$ & 2 & - & 24 \\
\hline & $\%$ & 0,07 & 0,00 & 0,61 \\
\hline
\end{tabular}

За весь період дослідження від донорства за маркерами гепатитів В та С було відведено 29 донорів (0,38\% від усієї кількості штатних донорів та осіб, що виявили бажання стати донорами): з них 23 особи - через наявність антитіл до гепатиту С, в тому числі 10 штатних донорів $(0,15 \%$ від усіх штатних донорів), та 13 осіб, що виявили бажання стати донорами $(1,78 \%$ від усіх осіб, що виявили бажання стати донорами); 6 донорів - через наявність HBsAg, у тому числі 4 штатні донори ( $0,06 \%$ від усіх штатних донорів), та 2 особи, шо виявили бажання стати донорами $(0,27 \%)$.

\section{Висновки}

1. Основне завдання відділу трансфузіології полягає у заготівлі компонентів крові, які цілком відповідають сучасним вимогам до безпеки гемотрансфузійних середовищ.

2. Виявлення позитивних маркерів вірусного гепатиту В за період з 2013-2015 р. у штатних донорів у 4,5 рази нижче, ніж в осіб, що виявили бажання стати донорами.

3. Виявлення позитивних маркерів вірусного гепатиту С за період з 2013-2015 р. у штатних донорів у 12 разів нижче, ніж в осіб, що виявили бажання стати донорами.

4. Низьке виявлення маркерів вірусних гепатитів В та С та динаміка зниження цих показників у штатних донорів пов'язані з ретельним відбором донорських кадрів, інформуванням донорів про можливі ризики зараження гемотрансфузійними інфекціями та пропагандою здорового способу життя. 


\section{Література}

1. Гепатит В. Информационный бюллетень ВОЗ. Март 2015 г.

2. Дзюблик I. В. Парентеральні вірусні гепатити. - Київ, 2005.

3. Долгов В. В. Клиническая лабораторная диагностика: национальное руководство; в 2т. - Т. ІІ / В. В. Долгов, В. В. Меньшиков. - М. : ГЭОТАР-Медиа, 2012. $808 \mathrm{c}$.

4. Вирусный гепатит C: современные возможности диагностики (клиническая лекция) / Дуда А. К., Бойко В. А. и др. // Актуальная инфектология. - 2015. № 4 (9). - C. 9-16.

5. Кишкун А. А. Иммунологические и серологические исследования в клинической практике / А. А. Кишкун. - М. : ООО «Медицинское информационное агентство», 2006. - $356 \mathrm{c}$.

6. Осипов Д. М. Маркеры вирусных гепатитов В и С у доноров и трансфузионнозависимых больных: автореф. дисс. на соискание научной степени канд. мед. наук: спец. 14.00.29 «Гематология и переливание крови» / Д. М. Осипов. - Новосибирск, 2006. - 160 с.

7. Львов Д. К. Медицинская вирусология. - М. : Медицинское информационное агентство, 2008. - 656 с.

8. Рагимов А. А., Дашкова Н. Г. Основы трансфузионной иммунологии. - М. : Медицинское информационное агентство, 2004. - 280 с.

9. Ройт А. Иммунология / Перевод с английского; Ройт А., Бростофф Дж., Мейл Д. - М. : Мир, 2000. $592 \mathrm{c}$.

10. Учайкин В. Ф. Руководство по инфекционным болезням / В. Ф. Учайкин. - М. : ГЭОТАР-Медиа, 2002. $388 \mathrm{c}$.
11. Харченко Н. В., Порохницький В. Г., Топольницький В. С. Вірусні гепатити. - К. : Фенікс, 2002. - 296 с.

12. Цирроз печени при хроническом гепатите С у детей / Чуелов С. Б., Лейбман Е. А., Чередниченко Т. В. и др. // Детские инфекции. - 2013. - № 4. - С. 27-30.

13. R. Iorioetal. Chronic hepatitis $\mathrm{C}$ in childhood: an 18-year experience // Clin Infect Dis. - 2005. - 41. - P. 14311434.

14. GlobalCommunityHepatitisPolicyReport2014 // World Hepatitis Alliance, 2014.

15. EASL Recommendations on Treatment of Hepatitis C 2015 // J. Hepatol. - 2015. - Vol. 63. - P. 199-236. at: http://www.easl.eu/medias/cpg/HEPC-2015/Fullreport.pdf.

16. Lavanchy D. The global burden of hepatitis C // Liver International. - 2009. - Vol. 29, suppl. 1. - P. 74-81.

17. Management of chronic hepatitis B in childhood: ESPGHAN clinical practice guidelines Consensus of an expert panel on behalf of the European Society of Pediatric Gastroenterology, Hepatology and Nutrition / E. M. Soka, M. Paganelli, S. Wirth et al. // Journal of Hepatology. 2013. - Vol. 59. - P. 814-829.

18. Hepatitis C Among Blood Donors In ATeaching Hospital In North Central Nigeria / Nwannadi Ikenna Alexander, Alao Olusayo, Shoaga Lanre // IOSR Journal of Dentaland Medical Sciences (IOSR-JDMS) e-ISSN: 2279-0853, p-ISSN: 2279-0861. - Vol. 13, Issue 1 Ver. II (Jan. 2014). P. 20-23.

19. Guidelines for the screening, care and treatment of persons with hepatitis C infection // WHO, April 2014.

20. Hepatitis C in the WHO European Region // Factsheet, July 2015.

\title{
Dynamics in detection of markers of viral hepatitis $B$ and $C$ among blood donors and patients as an indicator of the quality of blood donor selection
}

\author{
Salamanina A. O., Yunatska O. V., Tretiakova I. A.
}

State Institution «Scientific and Practical Medical Centre for Children's Cardiology and Cardiac Surgery of Ministry of Health of Ukraine» (Kyiv)

An important issue of the safety of donor's blood is the spread of infections transmitted during blood transfusion, including viral hepatitis $\mathrm{B}$ and $\mathrm{C}$. The results of testing donors and patients for markers of viral hepatitis $\mathrm{B}$ and $\mathrm{C}$ conducted at the UCCC's Department of Transfusion Control during the period from 2013 until 2015 are presented. The research was done using IHL-analysis and ELISA. The material for the retrospective study was serum taken from 22,144 blood donors and patients, including 9090 samples taken from regular donors, 1,450 samples taken from individuals who wanted to become donors and 11,604 blood samples taken from patients. Tests of 23 samples $(0.22 \%)$ of donors were found to be positive for $\mathrm{HCV}$-antibodies, and tests of 6 samples $(0.057 \%)$ were found to be positive for hepatitis B surface antigen. Identification of markers of hepatitis $\mathrm{C}$ among donors shows a stable downward trend. The frequency of detection of HBsAg in regular blood donors remains low, and the frequency of detection of HBsAg in individuals who want to become donors decreases.

Key words: transfusion infection, hepatitis B, hepatitis C, blood transfusion, IHL-analysis, ELISA. 